DOI: https://doi.org/10.47264/lassij.4.2.3

Vol. 4, No. 2, (July-December 2020): 24-41

Research Article

URL: https://www.ideapublishers.org/index.php/lassij

\title{
Macroeconomic Determinants of Brain Drain in the Era of Globalization: Evidence from Pakistan
}

\author{
Shazia Kousar ${ }^{1}$, Farhan Ahmed ${ }^{2 *}$ and S. Arfa Anam Bukhari ${ }^{3}$
}

1. Department of Economics, University of Jhang, Jhang, Punjab, Pakistan.

2. Department of Economics \& Management Sciences, NED University of Engineering \& Technology, Karachi, Pakistan.

3. Department of Management Science, The Superior College, Lahore, Pakistan.

\begin{abstract}
The Brain Drain (BD) is a cynosure of all the eyes because it has become a grave issue for Pakistan. Every year, thousands of students graduate from colleges and universities. Our markets cannot accommodate such a huge number of graduates so; these people prefer to migrate to other parts of the world. This paper attempts to investigate the factors affecting brain drain in Pakistan by utilizing the data for 1990 to 2018 . Indices of variables are constructed in this study to measure the potential of factors causing migration from Pakistan to other developed economies. Secondary data has been taken from the World Development Indicator (WDI) and the Bureau of Emigration and Overseas Employment (BEOE). This study finds that in long run governance, financial stability, the standard of living, and infrastructure have a negative and significant impact on the dependent variable (Brain drain). Social openness does not show a significant impact on brain drain in the long run. This study concludes that brain drain in developing nations is a serious matter and it should be addressed on a priority basis. This study helps policymakers to develop policies to reduce the migration of highly skilled labour.
\end{abstract}

Keywords: Brain Drain, Governance, Financial Stability, Infrastructure, Social Openness, Standard of Living, ARDL.

\section{Introduction}

In this era of globalization, highly skilled workers are continuously moving from poor to rich countries; this phenomenon raises a great deal of discussion and policy debate regarding the gains and loss of the brain drain. Highly skilled persons are needed in every part of the world specially trained technicians, engineers and health professionals; so developed countries attract skilled labour through better standards of living, quality of life, higher salaries, access to advanced technology, and more stable political polices. However, the developing nations face a considerable loss when these professionals migrate because they have invested in their education and training and pay high opportunity cost while the host country gains benefit directly because it did not bear the cost of educating them. Brain drain is becoming a global concern because of the importance of human capital in the growth process. Educated people are a nation's asset and this trend of migration of highly educated people results in loss of this great asset which affects the economy and society as a whole. It has been observed that flight of highly educated and intellectuals folks create a great hurdle in the development of the poor 
nations because the investment in higher education and training by the native country will be lost when highly educated and skilled individuals leave the motherland and do not come back (Bhagwati \& Hamada, 1974; Bhagwati, 1979; Durrani \& Mir, 2007; Kousar, Rehman et al., 2014; Monteleone \& Torrisi, 2010). According to Kobayashi (2014), brain drain would raise the growth rate and economic prosperity in the host country but for the home or native countries, it will negatively affect the economic growth process.

It has been observed that only in OECD countries, there are 59 million migrants and among them, 20 million are highly skilled and belong to Pakistan, Sri Lanka, and Bangladesh (Pedersen et al., 2008). As Lucas (2005) analysed that migration of people between 1977 and 2000 , it was found that 2 percent of the brain drain from native countries to other countries were skilled or professional. While 18 percent of people were electricians, carpenters, and masons but as these economies are growing day by day, their demand for skilled labour and highly qualified people is also increasing. Moreover, developed nations announce different incentives like scholarships, an H1-B visa program in the United States, High skilled program by the United Kingdom and Australia, Green Card Scheme for Technology experts in Germany to attract highly skilled workers from poor nations. Pakistan is a poor country that is facing a serious problem of unemployment and low economic growth. Therefore, it is generally argued that migration of skilled and semi-skilled worker help to overcome the problem of unemployment and accelerate economic growth by providing remittances. However, it works for a short period while in the long run period Pakistan will become a lack of professionals specifically in the health and education field and face economic and social loss created by the emigration of highly skilled professionals.

Figure 1: Pakistani out-migrant workers according to skill level, 2008-2019 (Percentages)

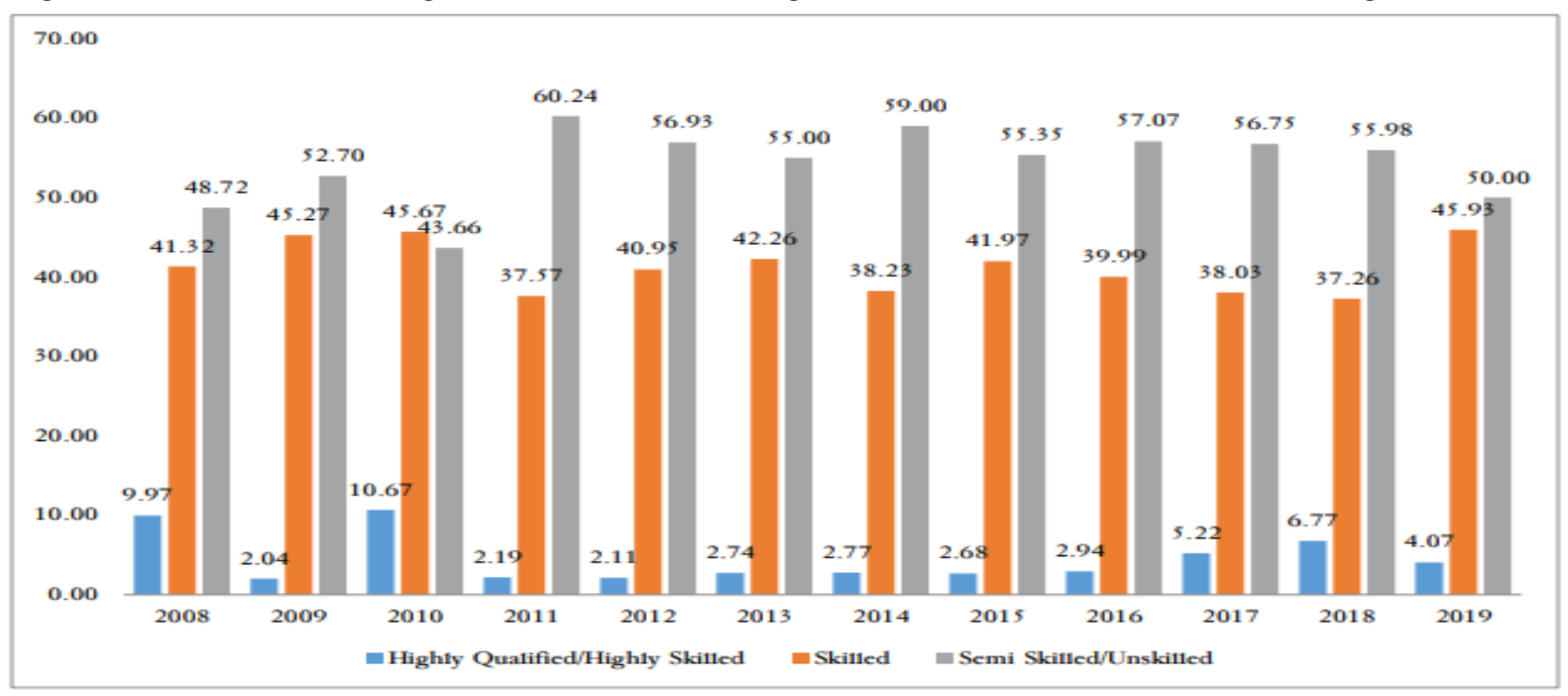

Source: BEOE database, various years.

Figure-1 indicates that the migration of highly skilled and semi-skilled workers is increasing from 2008 to 2019. The migration of skilled labour reached $45 \%$ in 2019 which the highest during the last decade. Similarly, the emigration of highly skilled labour was $10.67 \%$ in 2010 and it decreased to $4.07 \%$ in 2019 but still, it is alarming for the economic growth and development; as recently World Bank has identified that emigration of the skilled worker from Pakistan to rich countries is the main cause of its poor economic growth and development (Sajjad, 2011b). Therefore, to avoid the loss of trained professionals and unfavourable 
influence caused by the emigration of talented people; it is necessary to research and analyse the current situation of brain drain and explain the factors that push these professionals to migrate. This study is an attempt to understand the phenomenon of brain drain in-depth and identify the factors that push a skilled individual to migrate.

\subsection{Governance and Brain Drain}

Akusoba (2014), has carried out a study on workers of Nigerian University, why they are moving to developed countries. He concluded that low salaries, poor leadership, and high unemployment are the key drivers of work from their country to a more developed country. Khan et al., (2012) have focused on the political instability that the life of citizens is not safe, inflation is high, people are unable to get good jobs due to lack of job opportunities. They further suggested that the government should provide all better facilities to its citizens so that fewer people move to abroad. Hashmi et al. (2012) reported that intellectual minds in all sciences are leaving their homelands and moving towards U.S, Europe, Japan, and America due to political and economic changes. This study also explains that Germany has been the victim of this brain drain in 2005.it has been reported that nearly 144814 people left their native country due to unstable political and economic conditions and this is the highest rate at which migration took place since the end of World War II. Afzal et al., (2012) mentioned that due to uncertain and insecure situations in-country and due to unlawful situations in the country people move to developed countries. Sajjad (2011a) found many reasons why intellectual migration is taking place, he has analysed this through a questionnaire and he came to the conclusion that almost $33 \%$ of the people are leaving their home country due to political instability and life insecurity in the native country.

Solimano (2002) initiated through his research, the outlook of high income persuades the people of poor countries to migrate. He has explained that there are additional factors such as hostilities, political instability in the homeland, and racial biases that are affecting the decision of migration. Bang and Mitra (2011), documented that the quality and credibility of native political institutions largely affect the migration of skilled labour. Therefore, the literature identified that political instability and unlawfulness are the main push factors that cause skilled labour to migrate. However, this study contributes to the existing literature by investigating the role of governance in the brain drain by utilizing a multidimensional index of governance. This study utilized three dimensions of governance like political instability, corruption, and rule of law to compute the index of governance. On the basis of above literature, this study formulates the following hypothesis for empirical investigation:

$$
\mathrm{H} 1=\text { There is relationship between governance and Brain drain }
$$

\subsection{Financial Instability and Brain Drain}

Davis and Hart (2010) the most talented and intellectual minds are valuable assets in the world. It has been stated that developing countries lost their talent; developed economies ended up gaining it and results in a surplus accumulation of trained human resources trying to enter the workforce and a smaller amount of available jobs. The US remains the central hub globally for receiving skilled work force. Leon-Ledesma and Piracha (2004) have analysed the role of skilled worker migration and foreign remittances in emerging economies. The study concluded that that out-migration of skilled worker decrease unemployment level within the country and increase the inflow of remittances that ultimately boost the activities that involve self- 
employment. Consequently, the foreign exchange reserves increase and enhance the level of domestic investment, which accelerates the economic growth rate in poor nations.

Hussain (2004) explains that industrial uprising has provoked the call for overseas investment and trade to boost production competence. On the other side, immigrants receiving economies desire resources and competence seeking FDI in their labour concentrated economy. The study of Ahmad et al., (2003) show that Pakistan is continuously promoting policies that are in the favour of investors so that to attract more investors in Pakistan. Pakistan provides facilities to its investors through dividends, capital gains, and full repatriation of profits. In terms of legal protection, Act of 1976 Foreign Private Investment and Act of 1992 Protection of Economic Reforms emphasized the removal of equity caps on financial services, needless regulations, provides transparency and quality inputs to foreign investors. Hussain (2004) explains that industrial uprising has provoked the call for overseas investment and trade to boost production competence. On the other side, immigrants receiving economies desire resources and competence seeking FDI in their labour concentrated economy.

The extraordinary globalization marginalized characteristics such as low price inputs and regional uniformity besides poor political, economic situations of the developing world (UNCTAD, 1997). Kumar (2011) found a robust link between migration and financial development in developing nations while Karikari et al., (2016) investigated causality between migration and financial development and found that causality exists in the short-run period but there is causality among migration and financial development in the long-run period. However, no study has been found that investigated the relationship between financial development and migration. Therefore, this study is an attempt to fill the gap by investigating the role of financial development in-migration of skilled labour in Pakistan. On the basis of above literature, this study formulates the following hypothesis for empirical investigation:

\section{$\mathrm{H} 2=$ There is relationship between financial stability and Brain drain}

\subsection{Infrastructure and Brain Drain}

Macdonald (2008) he observed that private production is influenced by public investment and this was neglected and unnoticed by many other and it was found that a private infrastructure provides vital inputs for the private sector to enhance its production level. Companies examine public capital as an unpaid production factor when maximizing their profits. Mamatzakis (2008) has provided evidence that had justified the presence of scientific trends in investment in infrastructure. Investment in infrastructure had considered being a vital component to judge the economic performance of Greece. According to the author's calculations, which would be cost saving and would enhance the growth and productivity is public infrastructure. Straub (2008) distinguished a channel through which investment on infrastructure causes growth effect: economies of scale and scope. The author further tried to explain that if there would be betterment in transport infrastructure would lower the transportation cost and leads the economies towards healthier managing.

$\mathrm{Li}$ and $\mathrm{Li} \mathrm{(2008)} \mathrm{explains} \mathrm{that} \mathrm{investment} \mathrm{in} \mathrm{infrastructure} \mathrm{is} \mathrm{very} \mathrm{vital} \mathrm{to} \mathrm{heighten} \mathrm{the} \mathrm{growth}$ in the case of China from 1997-2006 and results concluded the same. Canning and Pedroni (2004) have used panel data range from 1950-1992 to analyse the role of infrastructure on GDP. Findings revealed that the infrastructure and GDP of a country had a long-run relationship. It further adds that infrastructure affects per capita income, which is driving labour 
force to other worlds. It tells us that simple panel tests allow us to segregate the signs and directions of the long-run effect of infrastructure on income in a way that is robust to the presence of unknown heterogeneous short-run causal relationships. The results of this paper present clear evidences that in most cases the infrastructure development induces long-run effects on growth. Davis and Hart (2010) the most talented and intellectual minds are valuable assets in the world. It has been stated that developing countries lost their talent; developed economies ended up gaining it and results in a surplus accumulation of trained human resources trying to enter the workforce and a smaller amount of available jobs. The US, which has strong infrastructure, remains the central hub globally for receiving skilled work force.

Ahmad et al. (2003) conducted a study on Pakistan and concluded that Pakistan is continuously promoting policies that are in the favour of investors so that to attract more investors in Pakistan. Pakistan provides facilities to its investors through dividends, capital gains, and full repatriation of profits because want to develop basic infrastructure and to create job opportunities within the country to restrict the emigration of skilled labour. Most of the literature tried to establish a link between infrastructure and economic growth but ignore the fact that people migrate from poor countries having poor infrastructure toward rich countries having well-established infrastructure (Dovlo, 2005; Kapur \& McHale, 2005); so there is dire need to investigate infrastructure as a push factor for migration of skilled labour. Therefore, this study is an attempt to investigate the impact of basic infrastructures like roads, energy generation, and the number of hospitals. On the basis of above literature, this study formulates the following hypothesis for empirical investigation:

$\mathrm{H} 3=$ There is relationship between infrastructure and Brain drain

\subsection{Social Openness and Brain Drain}

Lif (2016) explains that mobile networks either 3G's or 4G's reached up to $84 \%$ of the population have access to the internet due to this change in media and technology, people decision's to migrate also changes. Graham et al, (2013) analysed how social media or the internet stimulating the process of brain drain is through quick access to the whole world. People can get information about their desired country within no time. This access to information is affecting the social life of many migrants. Chaichian (2012), explained the role of the expansion of media and internet connections, how they have boosted process of globalization and which leads to international migration from Iran to USA (Gertner et al., 2007; Urban, 2002) Marketing strategies also plays a vital role in fascinating people to make their decisions for migration. Similarly, some studies found that Digital media helps to give perspective about the culture which increases openness and increases the probability ratio of migration. It is explained that openness act as a door to provide opportunities to migrate (Massey et al., 1999; Wegge, 1998).

According to Stevenson (2009), the decision of migration is linked with the information available on online sources; the internet offers its users with the latest, customized, and interactive information about their desired places. The Internet also helps in improving access to other social networks. It convinced that internet affects the migration decisions and actions. No study has been found in the context of Pakistan that investigates the role of the internet and media in brain drain. Therefore, this study is an effort to extend the literature by providing insights about the role of social openness in migration. On the basis of above literature, this study formulates the following hypothesis for empirical investigation: 
$\mathrm{H} 4=$ There is relationship between social openness and Brain drain.

\subsection{Standard of Living and Brain Drain}

Ali et al., (2015) another piece of research reported the factors which are the root cause of dragging skilled people from Pakistan to the rest of the World. After analysing the results, it has been found that young students who belong to middle-class families tend to move to foreign for seeking standard education and for enhancing future opportunities. Altaf et al., (2015) they have found that there is a direct relationship between unemployment and people leaving their countries especially in the case of Pakistan by using a log-linear regression model. Arouri et al., (2014) examined the factors which are key contributors in brain drain in Pakistan and according to their findings, economic growth, and financial development lower brain drain but inflation, unemployment, and trade are positively linked with brain drain ear regression model. Mayda (2010) analysed the key factors of migration to OECD countries between 1980 and 1995. The author concluded that due to average income and income dispersion in origin countries people move to other countries. In this study, geographical, demographical, and cultural impact is also analysed.

Ahmad et al., (2008) analysed the time series data to identify the factors which are responsible for the brain drain from Pakistan. They got the results that are showing a positive relationship between immigration and unemployment and the same was the case with inflation. There was a positive impact of inflation on brain drain whereas a negative relationship between real wage rates. Eggert et al., (2007) calculated a two-region model by conducting a study that focused on the relationship between migration unemployment and education. According to the results the regions that are poor, have low wages and a high unemployment rate, for this reason, skilled labour prefers to move to rich regions. On the basis of above literature, this study formulates the following hypothesis for empirical investigation:

$\mathrm{H} 5=$ There is relationship between standard of living and Brain drain

Figure 2: Conceptual Framework

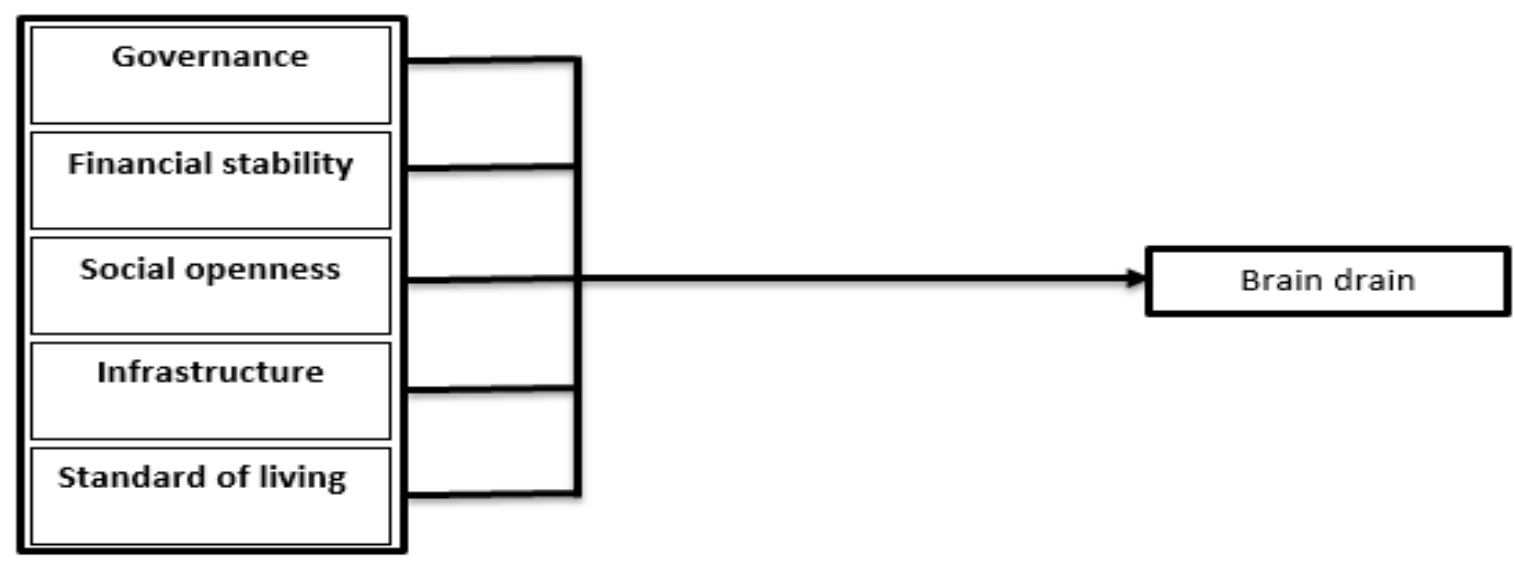

\section{Methodology and Data Sources}

Since the aim of the study is to determine the impact of macroeconomic factors on brain drain in Pakistan; so this study identified governance, financial stability, infrastructure, social openness, and standard of living as major macroeconomic determinant that causing the flight 
of intellectuals from Pakistan. Data of variables are taken from the world development indicator (WDI) and the Bureau of Emigration and overseas employment (BEOE) over the period of 1990 to 2018. Now days the utilization of secondary data becomes more predominant when a vast amount of primary data are being collected and archived by the researcher all over the world. Moreover secondary data is more reliable to generalize the findings of the study (Andrews et al., 2012) and utilization of secondary data become more important when researchers have limited time and resources (Johnston, 2017). This study converted annual data into quarter data by utilizing frequency conversion method in E.views.

Before empirical investigation it is necessary to check the long run co-integration among the series; usually Engle and Granger (1987) or Johansen (1988) are used to investigate the long run co-integration among series but if some series are integrated at level [I (0)] and some are integrated at first difference [I (1)], Engle-Granger and the maximum-likelihood-based Johansen methods may produce biased results regarding long-run co-integration (Engle \& Granger, 1987; Johansen, 1988). Therefore, this study utilized Autoregressive Distributed Lag (ARDL) bound test to investigate the long run co-integration among the series to avoid biased results. ARDL bound test method was proposed by Pesaran, Shin, and Smith (2001) that provide unbiased estimations if variables are integrated at level, I(0) or at first difference, I(1). ARDL model consists on "DL" (Distributed Lag), independent variables with lags that can affect dependent variable and "AR" (Autoregressive), lagged values of the dependent variable that can also affect its own current value.

The functional relationship between dependent and independent variables can be expressed as:

$$
\mathrm{BD}=\beta_{0}+\beta_{1} \mathrm{FINS}+\beta_{2} \mathrm{GOV}+\beta_{3} \mathrm{INFRA}+\beta_{4} \mathrm{SO}+\beta_{5} \mathrm{SOL}
$$

Where;

$$
\begin{aligned}
& \mathrm{BR}=\text { Net Brain Drain } \\
& \text { FINS = Financial stability } \\
& \text { GOV= Governance } \\
& \text { INFRA= Infrastructure } \\
& \text { SO=Social Openness } \\
& \text { SOL= Standard of Living }
\end{aligned}
$$

The following equation is specified to investigate the short run and long run impacts of different indices on brain drain:

$$
\begin{aligned}
& \Delta B D_{t}=\theta_{0}+\sum_{i=1}^{p} \theta_{1} \Delta B D_{t-i}+\sum_{i=1}^{p} \theta_{2} \Delta F I N S_{t-i}+\sum_{i=1}^{p} \theta_{3} \Delta G O V_{t-i}+\sum_{i=1}^{p} \theta_{4} \Delta I N F R A_{t-i} \\
&+\sum_{\substack{i=1 \\
\text { in }}}^{p} \theta_{5} \Delta S O_{t-i}+\sum_{i=1}^{p} \theta_{6} \Delta S O_{t-i}+\pi_{1} B D_{t-1}+\pi_{2} F I N S_{t-1}+\pi_{3} G O V_{t-1} \\
&+\pi_{4} I_{t-1}+\pi_{5} S O_{t-1}+\pi_{6} S O L_{t-1}+\mu_{t}
\end{aligned}
$$

In above equation, $\theta_{1}$ represent error correction term, $\theta_{2}, \theta_{3}, \theta_{4}, \theta_{5}, \theta_{6}$ represent short run coefficients while $\pi_{1}, \pi_{2}, \pi_{3}, \pi_{4}, \pi_{5}$ and $\pi_{6}$ represent long run estimates, $\mu_{t}$ is error term.

NetBD $=$ net brain drain per hundred thousand population of Pakistan in year t. (Farooq \& Ahmad, 2017). 
This study developed indices to measure brain drain, financial stability, governance, infrastructure, social openness and standard of living by taking averages of variables (Busse \& Hefeker, 2007) and study has provided the construction detail of indices in the following:

FINS $=$ averages of financial stability

Where;

FINS: REER + RTR + FDI

REER: real effective exchange rate index $(2010=100)$ relative to Pakistan.

RTR: Relative total reserves (plus gold) US\$

FDI: Relative foreign direct investment (net inflows) as \% of GDP.

According to Solimano (2002), besides many other factors, the human capital flight's direction and magnitude are influenced by the business cycle and economic prospects in host and destination countries. Mitra et al., (2011) investigated what impact financial liberalization had put on migration of highly intellectuals to OECD countries, indicators used in this research to present financial liberalisation is freedom and robustness of financial markets. Therefore, based on this literature the index of financial stability is created.

GOV: averages of governance indicators

Where;

GOV: POLS + COC + ROL

Whereas;

POLS: political instability relative to Pakistan (estimate)

COC: Control of corruption (estimate)

ROL: Rule of law (estimate)

Ghate et al., (2003) and Jong-A-Pin (2009) explicitly account for the multidimensionality of political instability and document differing impacts of various dimensions on growth.

INFRA: Averages of infrastructure

Where;

INFRA: RAIL + ELEC + NO OF PHYS

Whereas;

RAIL: Rail lines (total route $\mathrm{km}$ ) relative to Pakistan

ELEC: Electricity production \% of total relative to Pakistan

NO OF PHYS: Physicians (per 1000 people) relative to Pakistan.

Munir et al., (2018) explained that infrastructure has a pivotal role in dragging human capital out of the home country.

SO: averages of social openness

Where;

SO: TOUR + INTER + TRADE 
Whereas;

TOUR: International tourism (no of arrivals) relative to Pakistan

INTER: Internet users per hundred thousand people relative to Pakistan

TRADE: Trade in services as \% of GDP relative to Pakistan.

Chaichian (2012), explained the role of the expansion of media and internet connections, how they have boosted the process of globalization and which leads to international migration from Iran to the USA. So the following index for social openness is constructed.

SOL: Averages of the standard of living factors

Where;

SOL: TEDU + CPI + WATER

Whereas;

TEDU: Total government expenditure on education as \% of GDP relative to Pakistan.

CPI: Consumer price index relative to Pakistan

WATER: \% of the population having access to basic drinking water facilities relative to Pakistan.

According to different researchers, Gibson and Mckenzie (2011, 2012) and Clemans (2009) safety of family and living style are important in playing a role in migration. So the index for the standard of living is created by taking the averages of the following variables.

Table 1: Description of Variables

\begin{tabular}{|c|c|c|c|c|}
\hline Variables & Full form & Definitions & Measurement & Source \\
\hline \multicolumn{5}{|c|}{ Dependent variable } \\
\hline $\begin{array}{l}\text { Index of } \\
\text { Brain } \\
\text { Drain }\end{array}$ & $\begin{array}{l}\text { Net brain } \\
\text { drain }\end{array}$ & $\begin{array}{l}\text { Brain drain is defined as the } \\
\text { emigration of those skilled } \\
\text { people who have obtained their } \\
\text { advance training/education at } \\
\text { home country and they are } \\
\text { providing their services to other } \\
\text { worlds. }\end{array}$ & $\begin{array}{ll}\text { - } & \text { Highly qualified } \\
\text { - } & \text { Highly skilled } \\
\text { - } & \text { Skilled }\end{array}$ & BEOE \\
\hline \multicolumn{5}{|c|}{ Independent variables } \\
\hline $\begin{array}{l}\text { Index of } \\
\text { GOV }\end{array}$ & Governance & $\begin{array}{l}\text { Governance is defined as the } \\
\text { way countries/economies are } \\
\text { handled at the highest level; it } \\
\text { constitutes all the processes of } \\
\text { governing. }\end{array}$ & $\begin{array}{l}\text { - Political instability } \\
\text { - Corruption control } \\
\text { - Rule of law }\end{array}$ & WDI \\
\hline $\begin{array}{l}\text { Index of } \\
\text { FINS }\end{array}$ & $\begin{array}{l}\text { Financial } \\
\text { stability }\end{array}$ & $\begin{array}{l}\text { It is referred to as a state in the } \\
\text { financial system of a country that } \\
\text { can resist to economic shocks } \\
\text { and work smoothly to carry out } \\
\text { its basic functions. }\end{array}$ & $\begin{array}{l}\text { - Exchange rate } \\
\text { - Total reserves } \\
\text { - Foreign direct } \\
\text { investment }\end{array}$ & WDI \\
\hline $\begin{array}{l}\text { Index of } \\
\text { INFRA }\end{array}$ & Infrastructure & $\begin{array}{l}\text { It is termed as physical or basic } \\
\text { organizational structures that are } \\
\text { required for a society to work } \\
\text { (roads, power generation supply, } \\
\text { buildings) }\end{array}$ & $\begin{array}{l}\text { - Roads } \\
\text { - Electricity generation } \\
\text { - No of physicians }\end{array}$ & WDI \\
\hline
\end{tabular}




\begin{tabular}{|l|l|l|l|l|}
\hline $\begin{array}{l}\text { Index of } \\
\text { SO }\end{array}$ & $\begin{array}{l}\text { Social } \\
\text { openness }\end{array}$ & $\begin{array}{l}\text { It is defined as magnitude that } \\
\text { includes active imagination } \\
\text { fantasy) artistic or visual } \\
\text { sensitivity, attentiveness to inner } \\
\text { feelings, preference for variety, } \\
\text { and intellectual curiosity. }\end{array}$ & $\begin{array}{l}\text { Tourism(no of arrivals) } \\
\text { - Internet user's }\end{array}$ & WDI \\
\hline $\begin{array}{l}\text { Index of } \\
\text { SOL }\end{array}$ & $\begin{array}{l}\text { Standard of } \\
\text { living }\end{array}$ & $\begin{array}{l}\text { It is defined as the degree of } \\
\text { necessities, comfort, and wealth } \\
\text { that is available to society. }\end{array}$ & $\begin{array}{l}\text { Total government } \\
\text { expenditure on } \\
\text { education } \\
\text { Consumer price index } \\
\text { Individuals having } \\
\text { access to basic } \\
\text { drinking water }\end{array}$ & WDI \\
\hline
\end{tabular}

\section{Empirical Findings}

Table-2 provides the summary of statistics for all variables. Moreover, it explains the normality of data whether our residuals are normally distributed or not. So results indicated that data is normally distributed because the probability value is greater than 0.05 ; so the study accept null hypothesis that residuals are normally distributed.

Table 2: Descriptive Statistics

\begin{tabular}{|l|l|l|l|l|l|l|}
\hline & BD & GOV & FINS & INFRA & SO & SOL \\
\hline Mean & 51572.56 & -0.980955 & $3.61 \mathrm{E}+09$ & 2619.185 & 248292.4 & 33.01846 \\
\hline Median & 33320.07 & -0.985770 & $3.81 \mathrm{E}+09$ & 2618.932 & 276900.9 & 32.91242 \\
\hline Maximum & 146502.3 & -0.727127 & $7.43 \mathrm{E}+09$ & 2621.221 & 392911.3 & 37.61031 \\
\hline Minimum & 11967.13 & -1.184940 & $3.27 \mathrm{E}+08$ & 2617.959 & 121252.6 & 31.00730 \\
\hline Std. Dev. & 39141.64 & 0.123041 & $2.14 \mathrm{E}+09$ & 0.868927 & 80056.64 & 1.533251 \\
\hline Skewness & 1.006068 & 0.265569 & -0.074178 & 0.771576 & -0.231429 & 0.924169 \\
\hline Kurtosis & 2.789750 & 2.292796 & 1.887004 & 2.731162 & 1.645861 & 3.665272 \\
\hline Jarque Bera & 1.00729 & 2.868232 & 4.622817 & 2.996508 & 2.509074 & 4.14946 \\
\hline Probability & 0.551 & 0.238 & 0.099 & 0.214 & 0.320 & 0.230 \\
\hline
\end{tabular}

According to the assumption of the classical linear model of regression error, the term should be homogenous, if this assumption of the constant error would be violated, the problem of the heteroscedasticity (HSK) will arise in the data. The presence of the heteroscedasticity will result in the spurious findings (give-biased coefficients). Moving on to the test to detect the problem of HSK, this study utilised the Breusch-Pegan-Godfrey test and the results are reported in the table-3. Results explains that data is free of heteroscedasticity as the Obs*R squared probability value is greater than 0.05 so it concludes that there is no HSK problem. So study accepts the null hypothesis.

Table 3: Heteroscedasticity Test, Breusch-Pagan-Godfrey

\begin{tabular}{|l|l|l|l|}
\hline F-statistic & 0.78193 & Prob. F & 0.7737 \\
\hline Obs*R-squared & 30.5883 & Prob. Chi-Square & 0.6810 \\
\hline
\end{tabular}

Variance inflation factor is utilised to identify the problem of multi-collinearity and results are reported in table-4. The results indicate that the values of centred VIF for all variables are less than 10 so this study concludes that there is no problem of Multi-collinearity in the model. 
Table 4: Multi-collinearity Diagnostics

\begin{tabular}{|l|l|l|l|}
\hline Variable & Coefficient Variance & Uncentred VIF & $\begin{array}{l}\text { Centred } \\
\text { VIF }\end{array}$ \\
\hline FINS & $6.79 \mathrm{E}-12$ & 19.61631 & 5.080669 \\
\hline GOV & $1.90 \mathrm{E}+09$ & 305.9347 & 4.685562 \\
\hline INFRA & 20394788 & 23045403 & 2.507580 \\
\hline SO & 0.006432 & 72.02123 & 6.712377 \\
\hline SOL & 3906096 & 702.9334 & 1.495336 \\
\hline C & $1.40 \mathrm{E}+14$ & 23090781 & NA \\
\hline
\end{tabular}

\subsection{Unit Root Test}

Before going to ARDL we need to check the unit root of all the variables. This test is applied for checking whether data is used for analysis is stationary or not. Data is said to be stationary if the probability value is less than 0.05 , which means that probability distribution remains unchanged. This study utilized a widely used test Augmented Dickey-Fuller (ADF) to verify the stationarity of variables and results are reported in table-5. The results of ADF show that there is no unit root so here I accept the $\mathrm{H}_{\mathrm{o}}$ that is there is no unit root present in the data and I can further proceed for other results. The table- 5 explains that all the variables are stationary at first difference 1(1) at a 5\% significance level.

Table 5: Results of ADF Unit Root Test

\begin{tabular}{|l|l|l|l|}
\hline Variables & T stats & Probability & Level of Integration \\
\hline BD & -2.114 & 0.0338 & $1(1)$ \\
\hline FINS & -4.9951 & 0.0001 & $1(1)$ \\
\hline GOV & -3.2998 & 0.0180 & $1(1)$ \\
\hline INFRA & -3.0036 & 0.0387 & $1(1)$ \\
\hline SO & -3.4383 & 0.0123 & $1(1)$ \\
\hline SOL & -2.6459 & 0.0087 & $1(1)$ \\
\hline
\end{tabular}

The dependence of the $\mathrm{Y}$ variable on the $\mathrm{X}$ variable, $\mathrm{Y}$ variable responds to the $\mathrm{X}$ variable with a lapse of time. This lapse of time is called the lag. There is no hard and fast rule for selecting the optimal lag it is an empirical issue. According to Bahmani-Oskooee \& Rehman (2005), the results of ARDL are sensitive to the lag length. For annual data, we can take 1 or 2 lags or up to 4 lags. The lags for annual data are usually small. For quarterly data, the appropriate lags can be from 1 to 8 . For monthly data 6,12 , or 24 are the appropriate lags. The table- 6 presents the values of $\mathrm{F}$ stats to select which lag length is the optimal lag length. The results show different criteria to select the lag length but in this case, Schwarz Criteria (SC) is used to select the optimal lag, which is 6 .

Table 6: Lag Length Criteria

\begin{tabular}{|l|l|l|l|l|l|l|}
\hline \multicolumn{1}{|c|}{ Lag } & Log L & LR & FPE & AIC & SC & HQ \\
\hline 0 & -3801.332 & NA & $8.76 \mathrm{e}+33$ & 95.18331 & 95.36196 & 95.25493 \\
\hline 1 & -3099.644 & 1280.581 & $5.20 \mathrm{e}+26$ & 78.54111 & 79.79167 & 79.04249 \\
\hline 2 & -2985.603 & 191.0191 & $7.51 \mathrm{e}+25$ & 76.59008 & 78.91255 & 77.52122 \\
\hline 3 & -2972.167 & 20.49018 & $1.37 \mathrm{e}+26$ & 77.15417 & 80.54856 & 78.51508 \\
\hline 4 & -2961.570 & 14.57125 & $2.79 \mathrm{e}+26$ & 77.78924 & 82.25554 & 79.57991 \\
\hline 5 & -2698.795 & 321.8991 & $1.09 \mathrm{e}+24$ & 72.11987 & 77.65808 & 74.34030 \\
\hline 6 & -2606.738 & $98.96090^{*}$ & $3.28 \mathrm{e}+23^{*}$ & $70.71845^{*}$ & $77.32858^{*}$ & $73.36864^{*}$ \\
\hline
\end{tabular}




\begin{tabular}{|l|l|l|l|l|l|l|}
\hline 7 & -2582.585 & 22.34130 & $5.96 \mathrm{e}+23$ & 71.01464 & 78.69667 & 74.09458 \\
\hline 8 & -2557.383 & 19.53195 & $1.22 \mathrm{e}+24$ & 71.28457 & 80.03852 & 74.79428 \\
\hline
\end{tabular}

\subsection{Bound Test}

The bound test helps to tell whether we would be having a long-term relationship between variables. To run the ARDL test first there is dire need to run the bound test. It termed as authoritative apparatus to verify the affiliation and if it would be confirmed from the results, that co-integration exists then goes for ARDL. The table-7 explained the results of the bound test and the criteria to justify long run co-integration the value of $F$ should come higher than the other bound values. The results of bound test indicated that the value of $F$ is 4.961809 , which is above than lower and upper bound; so proving that there is a long run relationship, link among the variables and we can move to run ARDL.

Table 7: Results of Bound Test

\begin{tabular}{|l|l|l|}
\hline Test & Value & $\mathrm{K}$ \\
\hline F. Statistics & 5.389705 & 5 \\
\hline Significance Level & Lower Bound & Upper Bound \\
\hline $10 \%$ & 2.08 & 3 \\
\hline $5 \%$ & 2.39 & 3.38 \\
\hline $2.5 \%$ & 2.7 & 3.73 \\
\hline $1 \%$ & 3.06 & 4.15 \\
\hline
\end{tabular}

\subsection{Auto Regressive Distributed Lags}

ARDL termed as Autoregressive distributed lag. It is a co-integration approach, which is introduced by Pesaran et al., (1996); it as later further developed by Pesaran et al. (2001). ARDL has several advantages over other econometric techniques, like it does not require all variables to be stationary at the same level of integration i.e. 1(1). This approach can be used even when variables are integrated at 1(0) and 1(1). They further argued that ARDL provides robust results and more reliable results in the case of existence of long run relationship among variables. ARDL can also be used when dealing with small sample sizes. The long run ARDL estimates are reported in table- 9 and results show that governance has a negative and significant impact on brain drain $\left(\beta=-433693.70^{*}\right)$. One unit increase in brain drain will cause more than one unit change in governance in the long run. If the government/state does not provide an environment where people feel secure they would prefer to get absorbed in the developed countries (Bang \& Mitra, 2011).

Inhabitants of Pakistan do not have faith in the state. There is no rule and law, no control over corruption, and due to political instability in the country, investors are not ready to invest in productive sectors, which have increased the unemployment ratio. There is no accountability in the country; people feel that their lives are not secure. No system of merit prevails in the country, for getting job people to need to pay a lot of money as a bribe it creates employment discrimination. Institutional quality of the origin country plays a significant role, different aspects of institutional structure have different impacts on brain drain, for example, the transparency of governance, and it can be reflected by the quality of bureaucracy and the level of corruption all these institutional factors increase the selection of migrants from a developing economy to developed ones (Mackey \& Liang, 2013). Fascinatingly, the degree of 
democratization of society and the apparent credibility of a government in terms of its capability to guard property rights, implement contracts, and execute desired programs has a significant impact on brain drain. If the transparency factor is high, it reflects a high quality of the bureaucracy, a low corruption level, state political environment. In other words, a high value of the transparency factor reflects a high quality of existing institutions. This should predict a more favourable selection of highly skilled labour force to other developed countries (Mitra et al., 2011). Poor governance is driving the skilled labour out of the country and causing the problem of brain drain in the home country. Therefore, this study rejects the null hypothesis that is there is no significant relationship between the brain drain and governance

Financial stability has a negative and significant impact on brain drain $(\beta=-0.000029 *)$. When the financial stability of the country decreases, the reserve ratio and the FDI decreases, therefore, it will cause a brain drain. The foreign remittances and exchange rate also lead people to move abroad. Pakistan needs to promote friendly policies for investors. The 1976 act of foreign private investment had focused on removing the unwanted regulations; it has to ensure transparency and quality to the foreign investors. It has to focus on removing equity caps on financial services (Dar et al., 2017). Depressed financial stability means a decrease in economic growth, which leads to massive brain drain. The financial channels through which people can be productive for the country are involved in trade and through FDI. Therefore, in the long run, the study rejects the null hypothesis and accept the alternative hypothesis that there is a significant relationship between brain drain and financial stability. Infrastructure has a negative and significant impact on brain drain $(\beta=-46454.0221 *)$. One unit increase in infrastructure will bring more than one unit change in brain drain. Good infrastructure would help lower the cost of production, transportation cost. Examining the long-run effect of public infrastructure, improved and better infrastructure would increase employment opportunities, which leads to increased total factor productivity and growth in developing countries which will decrease the magnitude of brain drain (Vistnes et al., 2004). Therefore, study rejects the null hypothesis of no relationship between the infrastructure and the migration.

In the long run social openness has insignificant impact on brain drain $(\beta=0.221982)$. Social openness acts as a pull factor. The main components of this index are tourism, internet users, and trade in services. It does not have a significant impact. People have already ample opportunities to remain integrated with the homeland. They do not want to spend so much money for the sake of tourism (Farooq \& Ahmad, 2017).there is no doubt that the internet had blurred the boundaries and provided facilities to move across borders, but there is a substitute for migration and that is through virtual connectivity. Now everyone has easy access to video conferencing, online data can be exchanged anywhere at any time, there are many other means of interacting with the people who are living abroad and this could be done without actually traveling to places hence it has reduced the scope to migrate.

The standard of living has a negative significant impact on brain drain $\left(\beta=-5728.65506^{*}\right)$. People move to another world for better life quality, higher salaries, and a standard education system (Misau et al., 2010). Due to inflation prices of food, goods, energy, fuel rises which affects the entire economy. Inflation results in a decrease in job opportunities, people are hopeless and jobless so they prefer to move to another world for the sake of getting better standards of living. If we want to decrease the no of people migrating to developed countries, we are in dire need to provide the inhabitants with good education, clean water facilities, and low inflation. So this this study rejects the null hypothesis. Moreover, the short run estimates 
are reported in table- 8 . The value of error correction term (ECT) $\left(-0.082139^{*}\right)$ indicates that model is table and convergence speed is $8.2139 \%$.

Table 8: Short-Run ARDL Estimates

\begin{tabular}{|l|l|l|l|l|}
\hline Variable & Coefficient & Std. Error & t-Statistic & Prob. \\
\hline $\mathrm{D}(\mathrm{BD}(-1))$ & $-0.201943^{*}$ & 0.066770 & -3.024459 & 0.0041 \\
\hline $\mathrm{D}($ FINS) & $-0.000006^{*}$ & 0.000001 & -4.297374 & 0.0001 \\
\hline $\mathrm{D}($ GOV) & $34613.14^{*}$ & 14833.91 & 2.333380 & 0.0241 \\
\hline $\mathrm{D}($ INFRA $)$ & $8948.64^{*}$ & 2156.3 & 4.149874 & 0.0001 \\
\hline $\mathrm{D}($ SO $)$ & $-0.186584^{*}$ & 0.0256 & -7.272853 & 0.0000 \\
\hline $\mathrm{D}($ SOL $)$ & $-1637.3^{*}$ & 782.23 & -2.093148 & 0.041 \\
\hline $\mathrm{ECT}$ & $-0.082139^{*}$ & 0.012578 & -6.530618 & 0.0000 \\
\hline
\end{tabular}

Table 9: Long Run ARDL Results

\begin{tabular}{|l|l|l|l|l|}
\hline Variable & Coefficient & Std. Error & t-Statistic & Prob. \\
\hline FINS & $-0.000029^{*}$ & 0.000010 & -2.839529 & 0.0067 \\
\hline GOV & $-433693.70^{*}$ & 74407.4 & -5.828635 & 0.0000 \\
\hline INFRA & $-46454.0221^{*}$ & 8879.366 & -5.231682 & 0.0000 \\
\hline SO & $0.221982^{*}$ & 0.198409 & 1.118810 & 0.2690 \\
\hline SOL & $-5728.65506^{*}$ & 2611.214 & -2.193867 & 0.0333 \\
\hline C & 121533846 & 232694 & 5.222902 & 0.0000 \\
\hline
\end{tabular}

\section{CUSUM Test}

Figure 3: The plot of Cumulative Sum of Recursive Residuals

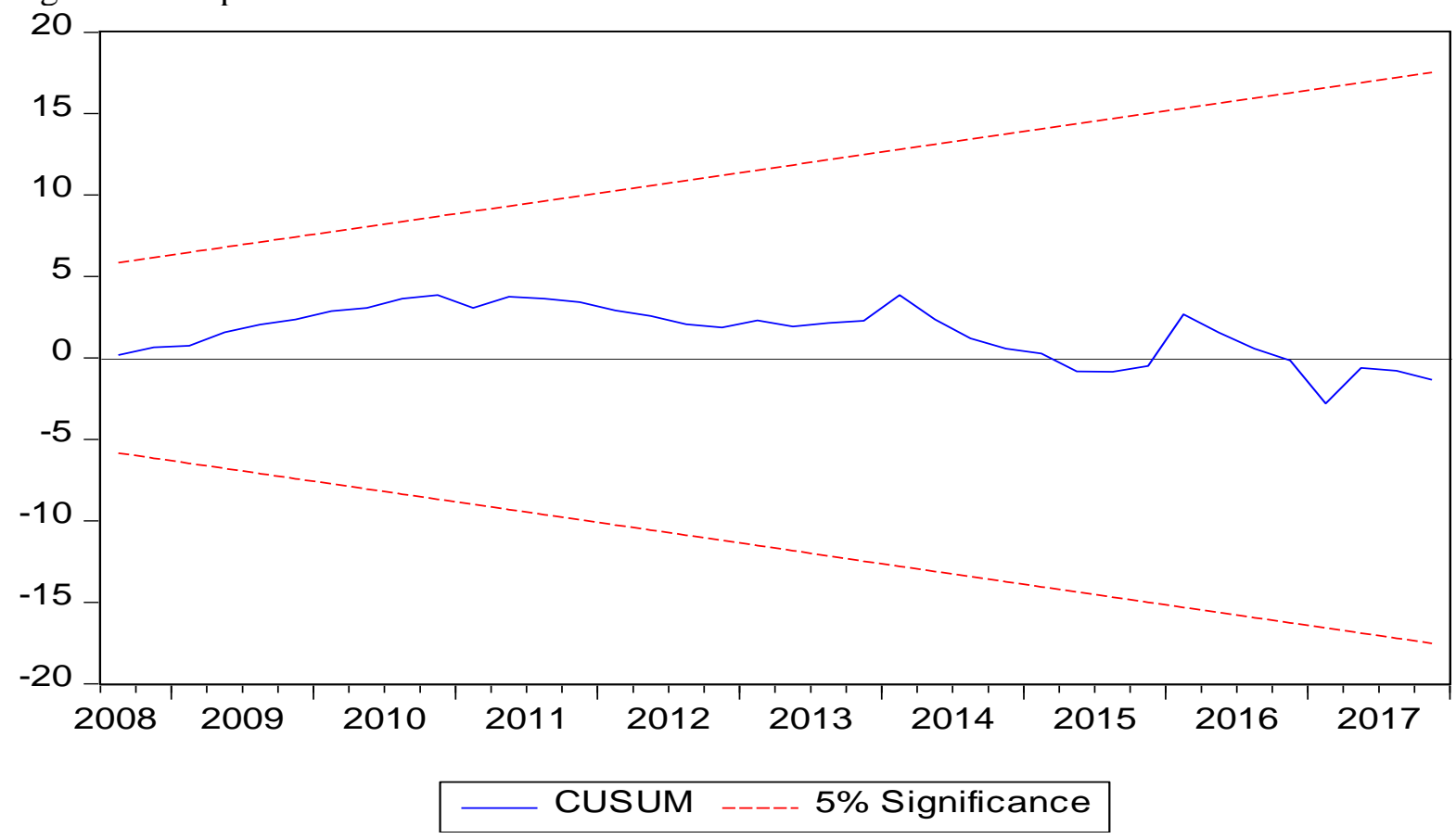

Now to check the stability of the chosen ARDL based on the error correction model using the Cumulative Sum of Recursive Residuals (CUSUM) given by (Brown et al., 1975). CUSUM test is used to tell whether the model is stable structurally or not and in this case it concludes that the plot remains within critical bounds at a $5 \%$ level of significance, so the model is structurally stable. 


\section{Conclusion}

In the nutshell, the brain drain hampers the development of a country. The present analysis of the situation focuses on the relation of Brain drain associated with governance, financial stability, infrastructure, social openness, and standard of living. The main objective of this study was to identify the determinants of the brain drain of the highly qualified highly skilled labour force from Pakistan. This study is based, on time series data ranging from 1996 to 2017. This study involves the construction of indices by taking averages of different variables. The dependent variable used in this study is the net brain drain and the independent variables are governance, financial stability, infrastructure, social openness, and d standard of living. The obtained results were derived by using available econometric techniques. The sign and values of coefficients support the migration theory and verify that these factors are the driving factors in the process of brain drain. The "Push" and "Pull" syndrome prevails everywhere in developing countries but it is more serious in Pakistan. The process of Brain drain has created negative impacts on the people of their own country as it has deprived the country of skilled, highly qualified, and trained human power.

Pakistanis, who had declared themselves as foreigners, never surrendered their dual nationality mainly due to higher wages, better living standards, and acknowledgment of their work. Unfortunately, in the last few years brain drain in Pakistan has increased significantly because of a lack of opportunities for career progression available in Pakistan. Our economy also lacks the space to accommodate the huge amount of skilled people that enter the labour force every year. Moreover, political instability, terrorist activities, lack of merit, lack of rule of law, are other contributing factors of brain drain in Pakistan. It is considered that first-generation is more true to their cultural roots, but later changes had occurred in their socio-cultural roots that would lead them to migrate in the case of Pakistan, they feel problems in adjusting themselves. In their view, they were not radicalized; still, they become very receptive and responsive to the depressing situation that prevails in the home country. They have been advised to be sincere and avoid violence acts, be calm, be like a good Muslim, lead a happy and wealthy life, and gaze for a vivid future for them and their children.

\section{References}

Afzal, S., Iqbal, H., \& Inayay, M. (2012). Terrorism and extremism as a non-traditional security threat post 9/11: Implications for Pakistan's security. International Journal of Business and Social Science, 3(24), 194-203.

Ahmad, M. H., Alam, S., Butt, M. S., \& Haroon, Y. (2003). Foreign direct investment, exports, and domestic output in Pakistan. The Pakistan Development Review, 42(4), 715-723.

Ahmad, N., Hussain, Z., Sial, M. H., Hussain, I., \& Akram, W. (2008). Macroeconomic determinants of international migration from Pakistan. Pakistan Economic and Social Review, 46(2), 85-99.

Akusoba, C. (2014). Understanding brain drain in Nigerian universities. http://lup.lub.lu.se/luur/download?func=downloadFile\&recordOId=4610804\&fileOI $\mathrm{d}=4610811$

Ali, A., Mujahid, N., Rashid, Y., \& Shahbaz, M. (2015). Human capital outflow and economic misery: Fresh evidence for Pakistan. Social Indicators Research, 124(3), 747-764.

Altaf, M., Atoofa, K., \& Ali, H. (2015). Two-Fold Aspect of Brain Drain in Pakistan: An Empirical Investigation. J. Asian Dev. Stud, 4(4), 200-206. 
Andrews, L., Higgins, A., Andrews, M. W., \& Lalor, J. G. (2012). Classic Grounded Theory to Analyse Secondary Data: Reality and Reflections. Grounded Theory Review, 11(1), 12-26.

Arouri, M., Rashid, Y., Shahbaz, M., \& Teulon, F. (2014). Short and long run determinants of brain drain: Evidence from Pakistan. http://v6.ipag.fr/wpcontent/uploads/recherche/WP/IPAG_WP_2014_113.pdf

Bahmani-Oskooee*, M., \& Rehman, H. (2005). Stability of the money demand function in Asian developing countries. Applied Economics, 37(7), 773-792.

Bang, J. T., \& Mitra, A. (2011). Brain drain and institutions of governance: Educational attainment of immigrants to the US 1988-1998. Economic Systems, 35(3), 335-354.

Bhagwati, J., \& Hamada, K. (1974). The brain drain, international integration of markets for professionals and unemployment: a theoretical analysis. Journal of Development Economics, 1(1), 19-42.

Bhagwati, J. N. (1979). International migration of the highly skilled: economics, ethics and taxes. Third world quarterly, 1(3), 17-30.

Brown, R. L., Durbin, J., \& Evans, J. M. (1975). Techniques for testing the constancy of regression relationships over time. Journal of the Royal Statistical Society: Series B (Methodological), 37(2), 149-163.

Busse, M., \& Hefeker, C. (2007). Political risk, institutions and foreign direct investment. European Journal of Political Economy, 23(2), 397-415.

Canning, D., \& Pedroni, P. (2004). The effect of infrastructure on long run economic growth. Harvard University, 99(9), 1-30. Working Paper. https://web.williams.edu/Economics/wp/pedroniinfrastructure.pdf

Chaichian, M. A. (2012). The new phase of globalization and brain drain. International Journal of Social Economics, 39(1/2), 18-38. http://doi.org.10.1108/03068291211188857

Dar, A. A., Bhatti, H. M. A., \& Muhammad, T. (2017). FDI and Economic Growth in Pakistan: A Sector Wise Multivariate Cointegration Analysis. Pakistan Development Review, 56(4), 67-90.

Davis, T., \& Hart, D. M. (2010). International Cooperation to Manage High-Skill Migration: The Case of India-US Relations. Review of Policy Research, 27(4), 509-526.

Dovlo, D. (2005). Taking more than a fair share? The migration of health professionals from poor to rich countries. PLoS Med, 2(5), e109. https://doi.org/10.1371/journal.pmed.0020109

Durrani, A., \& Mir, A. H. (2007). Pakistan Infrastructure Implementation Capacity Assessment. World Bank, https://openknowledge.worldbank.org/handle/10986/7671

Eggert, W., Krieger, T., \& Meier, V. (2007). Education, unemployment and migration. https://papers.ssrn.com/sol3/papers.cfm?abstract_id=1021958

Engle, R. F., \& Granger, C. W. (1987). Co-integration and error correction: representation, estimation, and testing. Econometrica: Journal of the Econometric Society, 55(2), 251-276.

Farooq, S., \& Ahmad, E. (2017). Brain Drain from Pakistan: An Empirical Analysis. Forman Journal of Economic Studies, 13, 55-81.

Gertner, R. K., Berger, K. A., \& Gertner, D. (2007). Country-dot-com: Marketing and branding destinations online. Journal of Travel \& Tourism Marketing, 21(2-3), 105-116.

Graham, M., Schroeder, R., \& Taylor, G. (2013). Re: search. New Media \& Society, 15(8), 1366-1373. 
Hashmi, M. A., Zeeshan, A., Mehmood, T., Naqvi, S. A. H., \& Shaikh, F. M. (2012). Factors driving brain drain in Pakistan: an exploratory view. J Asian Busi Strat, 2, 7-20.

Hussain, S. B. (2004). Encyclopedia of Capitalism: Facts On File, Inc. http://125.234.102.146:8080/dspace/handle/DNULIB 52011/2547

Johansen, S. (1988). Statistical analysis of cointegration vectors. Journal of economic dynamics and control, 12(2-3), 231-254.

Johnston, M. P. (2017). Secondary data analysis: A method of which the time has come. Qualitative and Quantitative Methods in Libraries, 3(3), 619-626.

Kapur, D., \& McHale, J. (2005). The global migration of talent: What does it mean for developing countries. CGD Brief (Washington: Center for Global Development). https://www.voced.edu.au/content/ngv:62692

Karikari, N. K., Mensah, S., \& Harvey, S. K. (2016). Do remittances promote financial development in Africa? SpringerPlus, 5(1), 1-21.

Khan, R., Khan, S., \& Zia, Y. E. (2012). Causes and impact of immigration on Pakistani young people on Pakistan and on host country (Great Britain). European Journal of Business and Social Sciences, 1(8), 91-98.

Kobayashi, S. (2014). The Effect to the Economic Growth by the Labor Migration: from the Viewpoint of the Stock of the Human Capital. Graduate School of Tokyo University of Foreign Studies. http://www.tufs.ac.jp/st/club/unohp/syuuron_zenbun_kobayashi2013.pdf

Kousar, S., Rehman, S., \& Rehman, A. (2014). Male migration and problems face by the family left behind: A case study of Thesil Daska. International Journal for Innovation Education and Research, 2(7), 20-42.

Kumar, R. R. (2011). Do remittances, exports and financial development matter for economic growth? A case study of Pakistan using bounds approach. Journal of International Academic Research, 11(1), 18-27.

León-Ledesma, M., \& Piracha, M. (2004). International migration and the role of remittances in Eastern Europe. International Migration, 42(4), 65-83.

Li, Y., \& Li, Z. (2008). Grey Relational Analysis between Infrastructure Investment and Economical Growth in China from 1997 to 2006. In Proceedings of 2008 International Conference on Construction \& Real Estate Management (Vol. 1, pp. 564-567).

Lif, O. (2016). Migration in the internet age: The 21st century: When refugees went online. https://lup.lub.lu.se/student-papers/search/publication/8873467

Lucas, R. E. (2005). International migration to the high-income countries: Some consequences for economic development in the sending countries. Are we on track to achieve the Millennium Development Goals. 127-181.

Macdonald, R. (2008). An Examination of Public Capital's Role in Production. Available at SSRN 1371042. https://papers.ssrn.com/sol3/papers.cfm?abstract id=1371042

Mackey, T., \& Liang, B. (2013). Restructuring brain drain: strengthening governance and financing for health worker migration. Global health action, 6(1), 1-7

Mamatzakis, E. C. (2008). Economic performance and public infrastructure: an application to Greek manufacturing. Bulletin of Economic Research, 60(3), 307-326.

Massey, D. S., Arango, J., Hugo, G., Kouaouci, A., \& Pellegrino, A. (1999). Worlds in Motion: Understanding International Migration at the End of the Millennium: Understanding International Migration at the End of the Millennium: Clarendon Press.

Mayda, A. M. (2010). International migration: a panel data analysis of the determinants of bilateral flows. Journal of Population Economics, 23(4), 1249-1274. 
Misau, Y. A., Al-Sadat, N., \& Gerei, A. B. (2010). Brain-drain and health care delivery in developing countries. Journal of Public Health in Africa, 1(1), e6. https://www.ncbi.nlm.nih.gov/pmc/articles/PMC5345397/

Mitra, A., Bang, J. T., \& Wunnava, P. V. (2011). Financial liberalization and the brain drain: a panel data analysis. https://papers.ssrn.com/sol3/papers.cfm?abstract_id=1929653

Monteleone, S., \& Torrisi, B. (2010). A Micro Data Analisys Of Italy's Brain Drain. https://mpra.ub.uni-muenchen.de/20995/

Munir, S., Elahi, I., \& Hussain Khan, I. (2018). Impact of Human Capital and Infrastructure Development on Economic Growth in Pakistan. European Online Journal of Natural and Social Sciences: Proceedings, 7(3), 127-140.

Pedersen, P. J., Pytlikova, M., \& Smith, N. (2008). Selection and network effects - Migration flows into OECD countries 1990-2000. European Economic Review, 52(7), 11601186.

Pesaran, M. H., Shin, Y., \& Smith, R. J. (1996). Testing for the Existence of a Long-run Relationship: Faculty of Economics. University of Cambridge.

Pesaran, M. H., Shin, Y., \& Smith, R. J. (2001). Bounds testing approaches to the analysis of level relationships. Journal of Applied Econometrics, 16(3), 289-326.

Sajjad, N. (2011a). Causes and solutions to intellectual brain drain in Pakistan. Dialogue, 6(1), 31-55.

Sajjad, N. (2011b). Causes and solutions to intellectual brain drain in Pakistan. Dialogue, 6(1), $1819-6462$.

Solimano, A. (2002). Globalizing talent and human capital: implications for developing countries. Santiago: UN. https://elibrary.worldbank.org/doi/abs/10.1596/0-8213$\underline{5388-8 \# \text { page }=325}$

Stevenson, B. (2009). The Internet and Job Search Studies of Labor Market Intermediation. University of Chicago Press.

Straub, S. (2008). Infrastructure and development: A critical appraisal of the macro level literature: The World Bank. https://elibrary.worldbank.org/doi/abs/10.1596/1813$\underline{9450-4590}$

Urban, F. (2002). Small town, big website?: Cities and their representation on the Internet. Cities, 19(1), 49-59.

Vistnes, I., Nellemann, C., Jordhøy, P., \& Strand, O. (2004). Effects of infrastructure on migration and range use of wild reindeer. The Journal of Wildlife Management, 68(1), 101-108.

Wegge, S. A. (1998). Chain migration and information networks: Evidence from nineteenthcentury Hesse-Cassel. The Journal of Economic History, 58(4), 957-986. 